\title{
Capital, rules or conflict? Factors affecting livelihood-strategies, infrastructure-resilience, and livelihood-vulnerability in the polders of Bangladesh
}

\author{
Sanchayan Nath $^{1}{ }^{10} \cdot$ Frank van Laerhoven $^{1} \cdot$ Peter Driessen $^{1} \cdot$ Md. Nadiruzzaman ${ }^{2}$
}

Received: 20 October 2019 / Accepted: 5 May 2020 / Published online: 18 May 2020

(c) The Author(s) 2020

\begin{abstract}
Coastal regions are most susceptible to the effects of climate change. To increase infrastructure-resilience of such regions, reduce livelihood-vulnerability of people living in such regions and equip them with appropriate livelihood strategies, governments have invested heavily in coastal infrastructure such as polders. This research is focused on the polders of Bangladesh. The effectiveness of Bangladesh's polders is disputed. No large-scale, evaluative, quantitative analysis of polders has yet been conducted. There is also only a limited number of evaluative studies on the factors which affect livelihood strategies, livelihood-vulnerability or infrastructure-resilience in polders. Therefore, the research question guiding this research is: What factors affect livelihood strategies, infrastructure-resilience, and livelihood-vulnerability in the polders of Bangladesh? These questions are answered by drawing on propositions from the Sustainable Livelihood Approach (SLA) using statistical analysis of a dataset of 137 polders. This dataset has been created from 76 survey-based interviews, secondary research and geo-spatial analysis. It is hypothesized that under different contextual settings, different combinations of livelihood resource endowments, lead to different combinations of livelihood strategies. These combinations of livelihood strategies lead to different outcomes after being moderated by different institutional, and political settings, under different contextual settings. This research demonstrates that various kinds of conflict-related and rule-making variables affect sustainability outcomes. Relationships proposed by the SLA are statistically significant and are generalizable across a large number of heterogeneous sites. Geological, geomorphological, climatic and hydrological conditions also affect livelihood decisions of polder-residents and also affect the condition of polder-infrastructure.
\end{abstract}

Keywords Institutions $\cdot$ Conflict $\cdot$ Vulnerability $\cdot$ Resilience $\cdot$ Polder $\cdot$ Sustainable livelihood approach

Handled by Rajarshi DasGupta, Institute for Global Environmental Strategies, Japan.

Electronic supplementary material The online version of this article (https://doi.org/10.1007/s11625-020-00818-6) contains supplementary material, which is available to authorized users.

Sanchayan Nath

s.nath@uu.nl

Frank van Laerhoven

F.S.J.vanLaerhoven@uu.nl

Peter Driessen

p.driessen@uu.nl

Md. Nadiruzzaman

nadir@iub.edu.bd

\section{Introduction}

The effects of climate change are being felt across the world (Cheung et al. 2009). Coastal regions are most susceptible to its effects. However, such regions are also densely populated and are an important source of livelihood for the local populace. Therefore, it is necessary to analyze the factors which affect the livelihood strategies adopted by local communities

1 Copernicus Institute of Sustainable Development, Utrecht University, Heidelberglaan 2, 3584 CS Utrecht, The Netherlands

2 The Center of the Earth System Research and Sustainability (CEN), University of Hamburg, Bundesstraße 53, 20146 Hamburg, Germany 
in coastal regions. In addition, it is also necessary to analyze if such strategies and other factors are affecting the vulnerability of people whose livelihood depends on the services provided by the world's coastal regions (Renaud et al. 2013).

To reduce the livelihood-vulnerability of people living in such regions, to equip them with appropriate livelihood strategies and to manage land-water dynamics along the coastal belt, governments have invested heavily in coastal infrastructure such as dykes, embankments, polders (defined in Section "Conceptualizing polders") and other polderlike-structures. Such infrastructure must be resilient to (e.g. climate-change related) shocks, to continue to protect the inhabitants of coastal regions (Renaud et al. 2013).

The first polders and polder-like-structures originated in the Netherlands in the 11th century. Over the years, other countries too have constructed such structures across their coastal regions: Bangladesh, China and India in Asia; Egypt \& Morocco in Africa, Belgium \& Denmark in Europe; USA in North America; and, Argentina and Venezuela in South America (Inniss and Simcock 2016).

In line with such concerns, this research is focused on the polders of Bangladesh. This is because Bangladesh is amongst the top six countries most affected by extreme weather events (Kreft et al. 2016). For decades it has been plagued by sea-level rise, increasing tidal surges, salt-water intrusion into its downstream riverine system, depleting water levels in its upstream riverine system, coastal flooding, land erosion as-well-as land subsidence, increased incidences of a wide range of extreme events ranging from droughts to cyclones, increasingly erratic precipitation, increasing temperatures, depleting water levels and arsenic contamination (Alam et al. 2017; GED, 2017; Adnan et al. 2019). The coastal belt of Bangladesh is more prone to extreme weather events as compared to the rest of the country (GED 2017).

The coastal belt of Bangladesh is characterized by more than 140 polders which have been constructed since the late1960s to protect the region from flooding, tidal surges and water-level rise (Alam et al. 2017). Bangladesh invests less than 2\% of its GDP in infrastructure development (WB 2015; GED 2017). Not-surprisingly, Bangladesh was ranked 127th globally in 'quality of infrastructure' by the World Economic Forum in its global competitiveness report of 2014-2015 (WB 2015). Therefore, the effectiveness of Bangladesh's polders is increasingly disputed and the resilience of such infrastructure needs to be studied in greater detail. Auerbach et al. (2015) have argued that hydrological structures (dykes, sluicegates, etc.) associated with these polders are unreliable. They are subject to erosion and sometimes get breached during extreme weather events (Adnan et al. 2019).

Polderization of the coastal belt in Bangladesh has had profound effects on the livelihood strategies of the local populace. While the amount of land used for agriculture has decreased, the amount of land used for aquaculture has increased (Akber et al. 2018). While contributing to the economic development of the region, these changes may have also led to increasing poverty levels, thus affecting livelihood-vulnerability in the coastal belt of Bangladesh (Mukhopadhyay et al. 2018).

In line with such concerns, the research question guiding this research is: what factors affect livelihood strategies, infrastructure-resilience, and livelihood-vulnerability in the polders of Bangladesh? The objective of this research is to increase our understanding of how livelihood resource endowments, physiographic variables, hydrological variables, institutional variables, political variables, and contextual variables affect livelihood strategies, infrastructureresilience, and livelihood-vulnerability in the polders of Bangladesh. These questions are answered using statistical analysis of a dataset of 137 polders in Bangladesh.

\section{Literature review and theoretical approach}

\section{Conceptualizing polders}

A polder can be conceptualized as a piece of land surrounded by embankments (Segeren 1982; Ishtiaque et al. 2017). The embankment separates this piece of land from the surrounding hydrological regime. In polders, embankments protect the enclosed land from flooding. Sluicegates are used to control the flow of water between the polder and the surrounding hydrological regime. Canals convey water to and from the embankment into various sections of the polder (Segeren 1982; Ishtiaque et al. 2017). As most polders are inhabited and are characterized by a wide range of livelihood strategies, they can be theoretically conceptualized as a coupled socio-hydrological system (Di Baldassarre et al. 2013).

The academic disciplines of hydrology and society have traditionally been studied as separate entities. Research in hydrology has often assumed that human agency is exogenous to hydrological or societal change. Similarly, the social sciences have ignored the bi-directional nature of the interaction between societal and hydrological systems (Pande and Sivapalan 2017). However, in a polder, interactions between the social system and the hydrological system are bi-directional. For instance, when an embankment is breached by an extreme event, saline water may flood agricultural lands within the polder, and disrupt the traditional ways of life for the local populace, and increase poverty levels. In contrast, the local populace may deliberately breach their embankment because they may feel that the flow of saline water may increase the aquaculture potential of the region, which in turn may lead to the economic development of the area. 


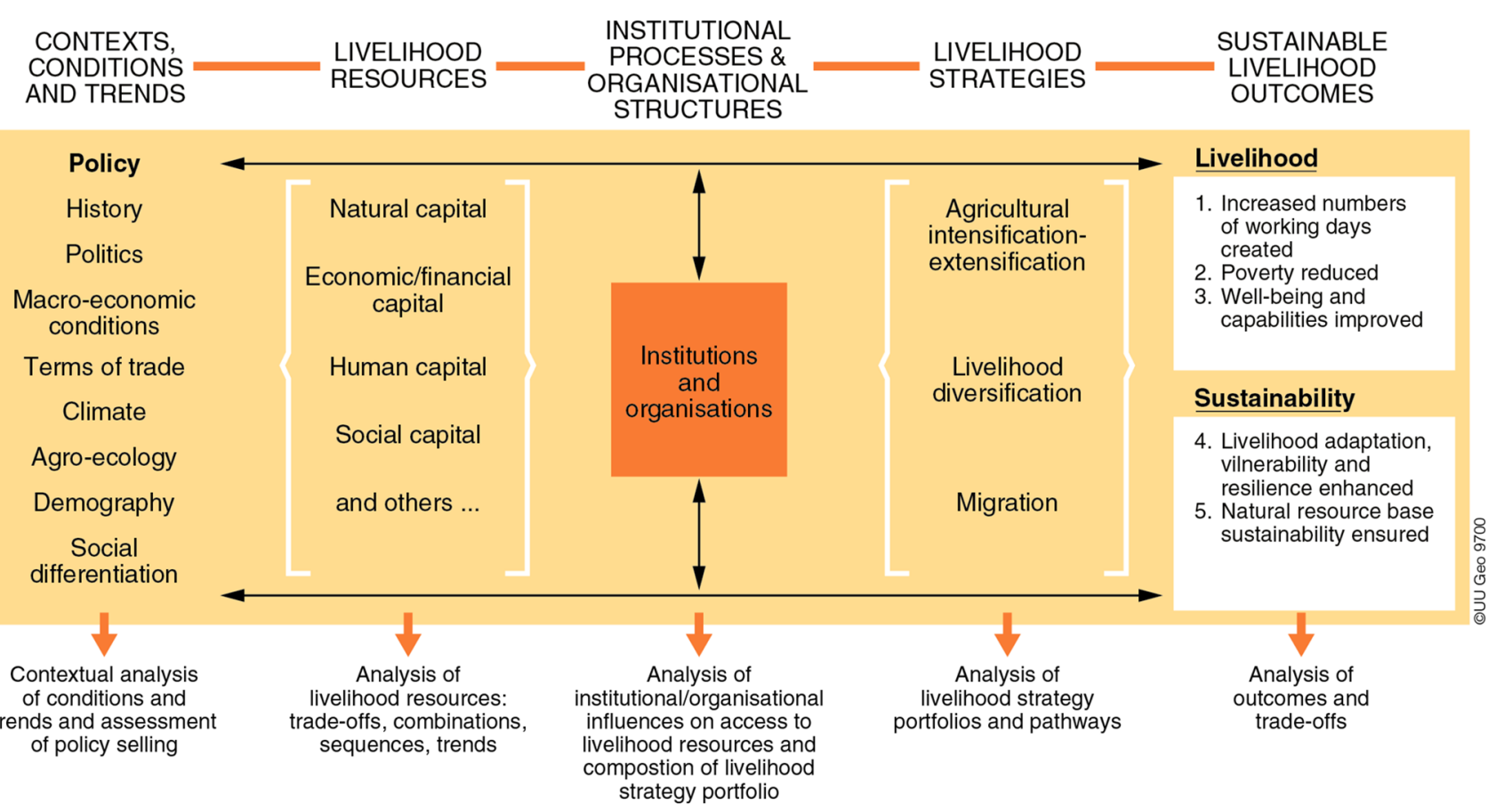

Fig. 1 Variables provided by the Sustainable Livelihood Approach Adapted from Scoones (2015)

In other words, a change in the hydrological system brought about either by the associated social system or the hydrological system itself affects the livelihood-vulnerability and infrastructure-resilience of the region.

\section{Livelihood-vulnerability and infrastructure-resilience}

The literature on vulnerability and resilience is characterized by conceptual fuzziness over whether they can be theoretically distinguished from each other (Gallopın 2006). The literature of resilience and the literature on vulnerability are both concerned with understanding how systems respond to stresses and disturbances. Both literatures also acknowledge the role of institutions in 'buffering' shocks (Nelson et al. 2007; Miller et al. 2010).

However, based on a comprehensive survey of such literature, Miller et al. (2010) argued resilience and vulnerability are 'related yet different' (Turner 2010). Resilience analyzes the effect of socio-ecological, biophysical, geophysical, ecological and engineering factors (and processes) on systemic change. In contrast, vulnerability analyzes the effect of socio-political and socio-economic factors (and processes) on systemic change (Nelson et al. 2007; Miller et al. 2010). Since this article is interested in the resilience of socio-hydrological structures such as polders (and associated infrastructures such as dykes, embankments and sluicegates), this article is narrowly focused on the concept of infrastructure-resilience. Therefore, as argued by Brand and
Jax (2007), McDaniels et al. (2008), Cutter et al. (2008) and Chang (2014), this article defines infrastructure-resilience as the ability of infrastructure in a system to consistently remain in a stable state or return to a stable state by withstanding, absorbing or adjusting to shocks and disturbances.

This article is interested in the vulnerability of social systems associated with hydrological structures such as polders. In these polders livelihood strategies of the local populace are actively defined by their interactions with polders and associated hydrological structures. Therefore, this article is narrowly focused on the concept of livelihood-vulnerability. As argued by Adger (2006) and Hahn et al. (2009), this article conceives livelihood-vulnerability as a measure of how secure the current livelihood strategies of the designated community are when exposed to various shocks and disturbances, as-well-as the capacity of the community to adapt their livelihood strategies in response to such shocks and disturbances.

\section{Studying livelihood-vulnerability and infrastructure-resilience in polders using the Sustainable Livelihood Approach}

This article draws on the Sustainable Livelihood Approach (henceforth referred to as SLA) to identify the factors which affect livelihood strategies, livelihood-vulnerability and infrastructure-resilience in polders. This is because, as discussed later, SLA is a useful tool for analyzing how structure (societal or hydrological) interacts with the human 


\begin{tabular}{|c|c|c|c|c|c|}
\hline & Dependent Variable & & \multicolumn{3}{|c|}{ Independent Variables } \\
\hline Eq. 1: & $\begin{array}{l}\text { Portfolio of } \\
\text { Livelihood } \\
\text { Strategies }\end{array}$ & $=$ & $\begin{array}{c}\text { Portfolio of } \\
\text { Livelihood } \\
\text { Resource } \\
\text { Endowments }\end{array}$ & + & $\begin{array}{l}\text { Contextual } \\
\text { Variables }\end{array}$ \\
\hline
\end{tabular}

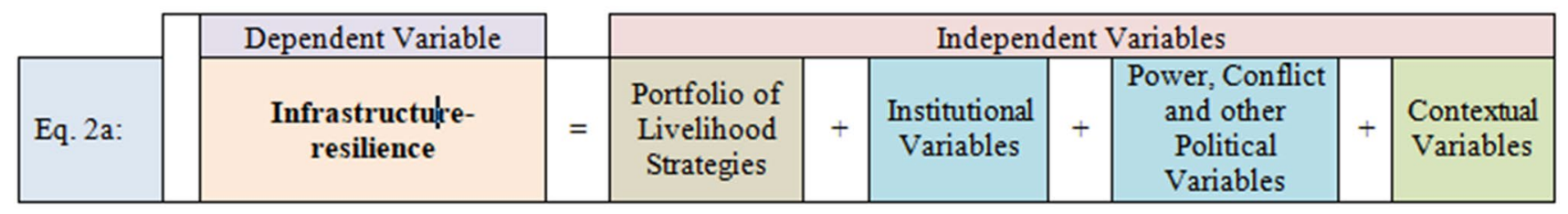

\begin{tabular}{|c|c|c|c|c|c|c|c|c|c|}
\hline & Dependent Variable & & \multicolumn{7}{|c|}{ Independent Variables } \\
\hline Eq. $2 b$ : & Livelihood-vulnerability & $=$ & $\begin{array}{l}\text { Portfolio of } \\
\text { Livelihood } \\
\text { Strategies }\end{array}$ & + & $\begin{array}{l}\text { Institutional } \\
\text { Variables }\end{array}$ & + & $\begin{array}{l}\text { Power, Conflict } \\
\text { and other } \\
\text { Political } \\
\text { Variables }\end{array}$ & + & $\begin{array}{l}\text { Contextual } \\
\text { Variables }\end{array}$ \\
\hline
\end{tabular}

Fig. 2 Theoretical model

agency to affect systemic outcomes (Scoones 1998, 2015). It can be used to study how climate change affects the livelihood strategies of people living in a polder and how such strategies shapes the vulnerability of this population or the resilience of the polder infrastructure (Mersha and van Laerhoven 2016).

The SLA emerged in a working paper by Chambers and Conway (1992). In the decades thereafter, a wide variety of empirical work based on this approach was conducted to understand how communities adapt their livelihood strategies in the face of various shocks and disturbances. This characteristic of the SLA makes it useful for analyzing how variables from both the social as-well-as the natural sciences are associated with livelihood-vulnerability, infrastructureresilience or adaptive capacity of a coupled system (Mersha and van Laerhoven 2016). Figure 1 Illustrates the variables associated with the SLA (Scoones 1998, 2015). Appendix 1 of the Supplementary File lists the definitions of these variables.

According to Scoones $(1998,2015)$, this framework of variables has been designed to serve as a 'diagrammatic checklist' of how various societal as-well-as contextual (hydrological, geographical, ecological, etc.) variables interact with each other. The approach can be applied across a wide range of scales-ranging from the individual-level to more aggregated regional-levels. The starting point of analysis within the approach is the identification of different kinds of resources available for use by the local populace. The framework identifies four main types of resources: natural, economic, social and human. However, other kinds of capital (such as physical capital) can also be included for analysis. The local population use varied combinations of such resources to develop various kinds of livelihood strategies (such as agricultural intensification/extensification, livelihood diversification or migration). This capability of people to successfully use diverse resources to develop diverse livelihood strategies may explain differences in the livelihood-vulnerability and infrastructure-resilience of the system they are a part of (Morse and McNamara 2013a). Such livelihood strategies when mediated by various institutional (rules, norms, customs, property tenure, markets, etc.) variables, in different contexts (hydrological, geographical, ecological, etc.), produce different kinds of outcomes (Scoones 1998, 2015). Two broad categories of outcomes are possible in the SLA: (a) livelihood-related-i.e. variation in livelihood strategies, variation in poverty-levels etc. and, (b) sustainability-related-i.e. variation in livelihood-vulnerability, infrastructure-resilience or adaptability, etc. The relationship between resources, livelihood strategies, contextual variables and sustainability-related outcomes such vulnerability \& resilience is mediated by institutional and political variables (Scoones 1998; McLennan and Garvin 2012; Morse and McNamara 2013b; Scoones 2015).

However, the SLA has its critiques: namely, (a) the political dimensions of human interactions (power, conflict, decision-making, etc.) have not been adequately captured in the approach (Allison and Horemans 2006; Moser 2008; Scoones 2015); (b) institutional variables have also not been fully integrated into it (de Haan and Zoomers 2005; Scoones 2015). In response to such critiques regarding the 
underdeveloped attention of SLA to the political and institutional dimension of human interactions, this article draws upon social-scientific empirical work (Naz and Buisson 2015; Ishtiaque et al. 2017) on polders to identify institutional and political variables which may affect outcome variables such as resilience and vulnerability in polders.

\section{Research methodology}

\section{Operationalizing variables and hypothesis}

The theoretical model guiding this research, as outlined in Fig. 2, has been derived from the Sustainable Livelihood Approach (Scoones 1998, 2015). As outlined by the research question in the Introduction section, there are two dependent variables: (a) Infrastructure-resilience, and (b) Livelihoodvulnerability. A wide range of independent variables are hypothesized to affect these dependent variables: Livelihood strategies, Livelihood resource endowments, Institutional variables, Political variables, and various Contextual variables (Socio-economic, Hydrological, Ecological, Geographic, Geomorphic, etc.). See Table 1 for more details on these variables. It is hypothesized that these independent variables affect the two dependent variables in a 2-staged manner:

(a) Under different contextual settings, different combinations of livelihood resource endowments, lead to different combinations of livelihood strategies (Eq. 1);

Livelihood Strategies $=\beta_{1} \times$ Livelihood Resource Endowments

$$
+\beta_{2} \times \text { Contextual Variables }+ \text { constant }
$$

(b) These combinations of livelihood strategies, lead to different outcomes after being moderated by different institutional, and political settings, under different contextual settings (Eqs. 2a \& 2b)

$\operatorname{logit}(p)=\beta_{1} \times$ Livelihood Strategies $+\beta_{2} \times$ Institutional Variables

$+\beta_{3} \times$ Power, Conflict and other Political Variables $+\beta_{4}$

$\times$ Contextual Variables + constant

where $p$ is the probability (Infrastructure-resilience varies between 0 and 1 )

$$
\begin{aligned}
\operatorname{logit}(p) & =\beta_{1} \times \text { Livelihood Strategies }+\beta_{2} \times \text { Institutional Variables } \\
& +\beta_{3} \times \text { Power, Conflict and other Political Variables }+\beta_{d} \\
& \times \text { Contextual Variables }+ \text { constant }
\end{aligned}
$$

where $p$ is the probability (Livelihood-vulnerability varies between 0 and 1)

\section{Study site}

The coastal belt of Bangladesh has more than 140 polders (Map 1). The dataset used for this article analyzes information on 137 polders under the administrative control of Bangladesh Water Development Board (BWDB), a public agency responsible for the administration of surface-water and ground-water resources in Bangladesh. Data-availability issues prevented the authors from collecting information on the rest of the polders.

\section{Research design}

Scoones (2015) argues that a wide range of research methods (quantitative, qualitative, deliberative and participatory) can be used to study the relationships encapsulated in the SLA. These relationships are 'linear in style' and have been formulated in a 'mechanical cause-effect' manner (Morse and McNamara 2013b). However, most studies using this approach have been qualitative in nature. Scoones (2015) therefore calls for more quantitative studies using this approach to statistically evaluate whether the relationships proposed by the approach hold across larger data-sets. In addition, Scoones (1998) argues that such relationships can be best tested by combining 'survey tools' with other qualitative and quantitative instruments for data collection and analysis. Therefore, survey-based interviews, secondary data collection and GIS (\& spatial) tools are used for data collection and processing. This article then uses multiple regression techniques on generalized linear models to evaluate the relationships proposed by the SLA for analyzing the factors which affect livelihood-vulnerability and infrastructureresilience of polders.

This article is the first-ever attempt at using regression techniques for analyzing broad \& generalizable findings about the various factors which affect resilience and vulnerability in polders. A detailed review of the literature using the string "polders regression OR statistics" on Google Scholar $\&$ Scopus reveals that no such large-scale, cross-sectional, quantitative analysis of polders has yet been conductedneither for Bangladesh nor globally.

\section{Data collection and processing}

Three kinds of data collection and data processing techniques have been used in this article: surveys, secondary research and GIS (\& spatial) analysis. Data was collected for only those variables identified by the theoretical model outlined earlier. The data collection process was 


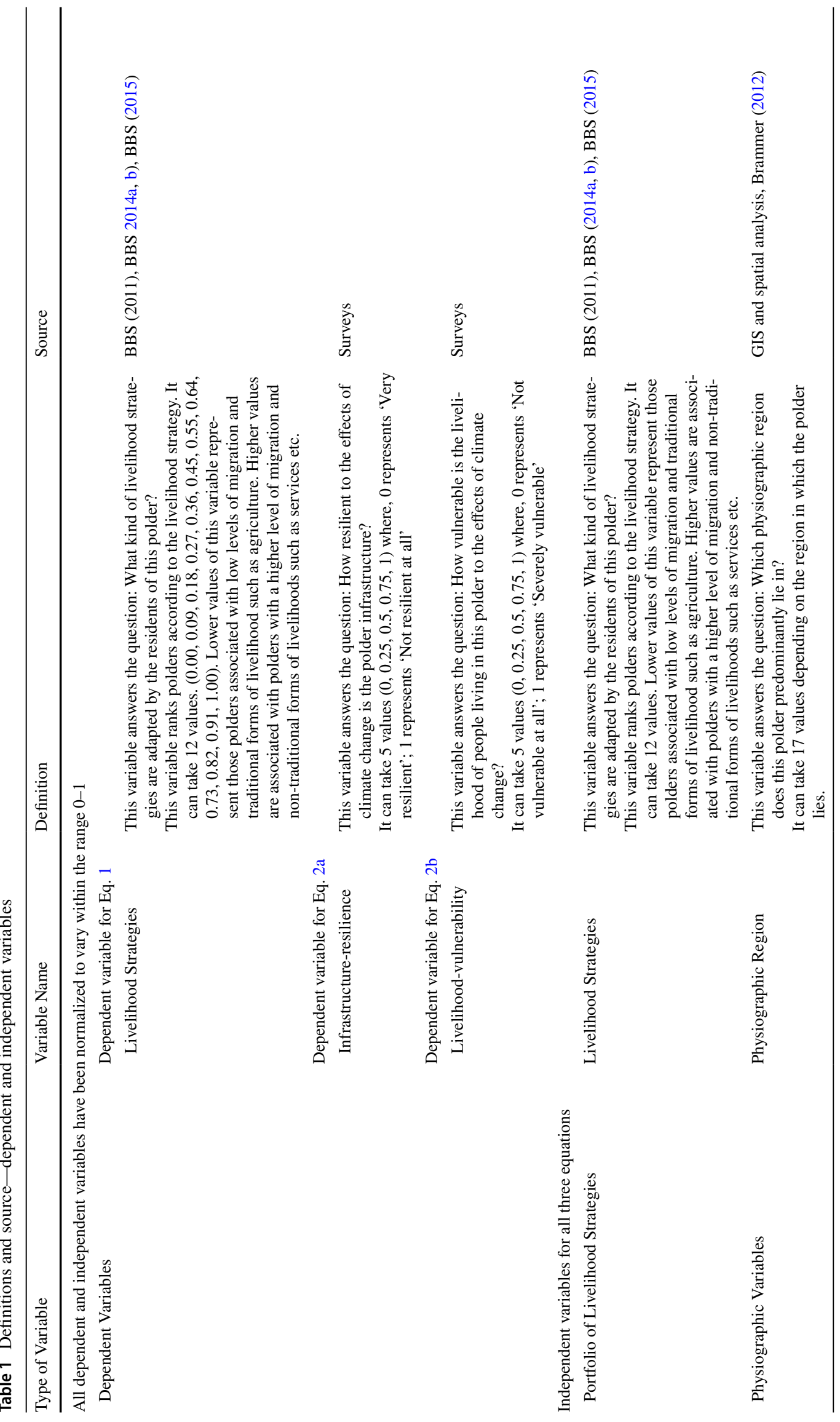




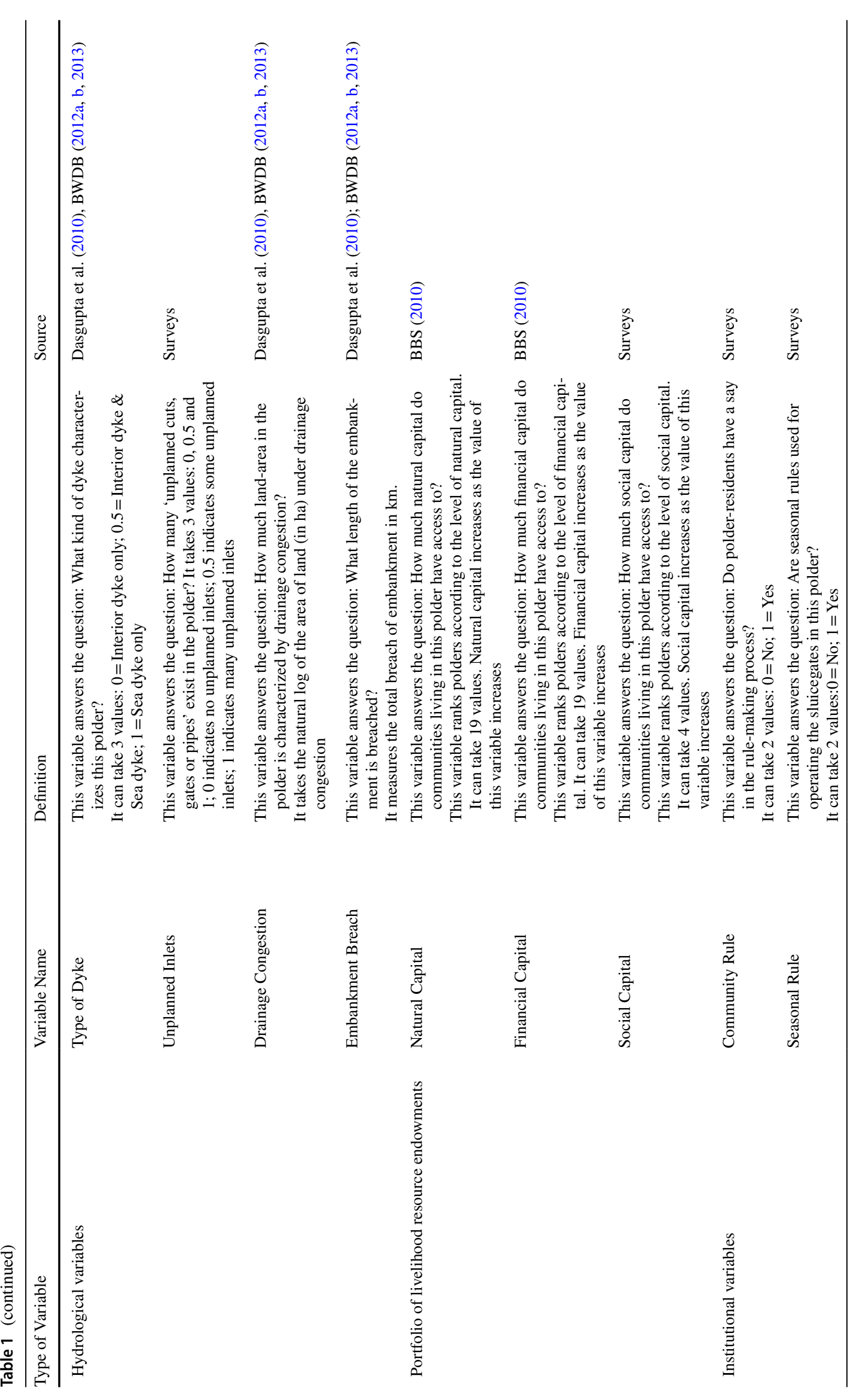




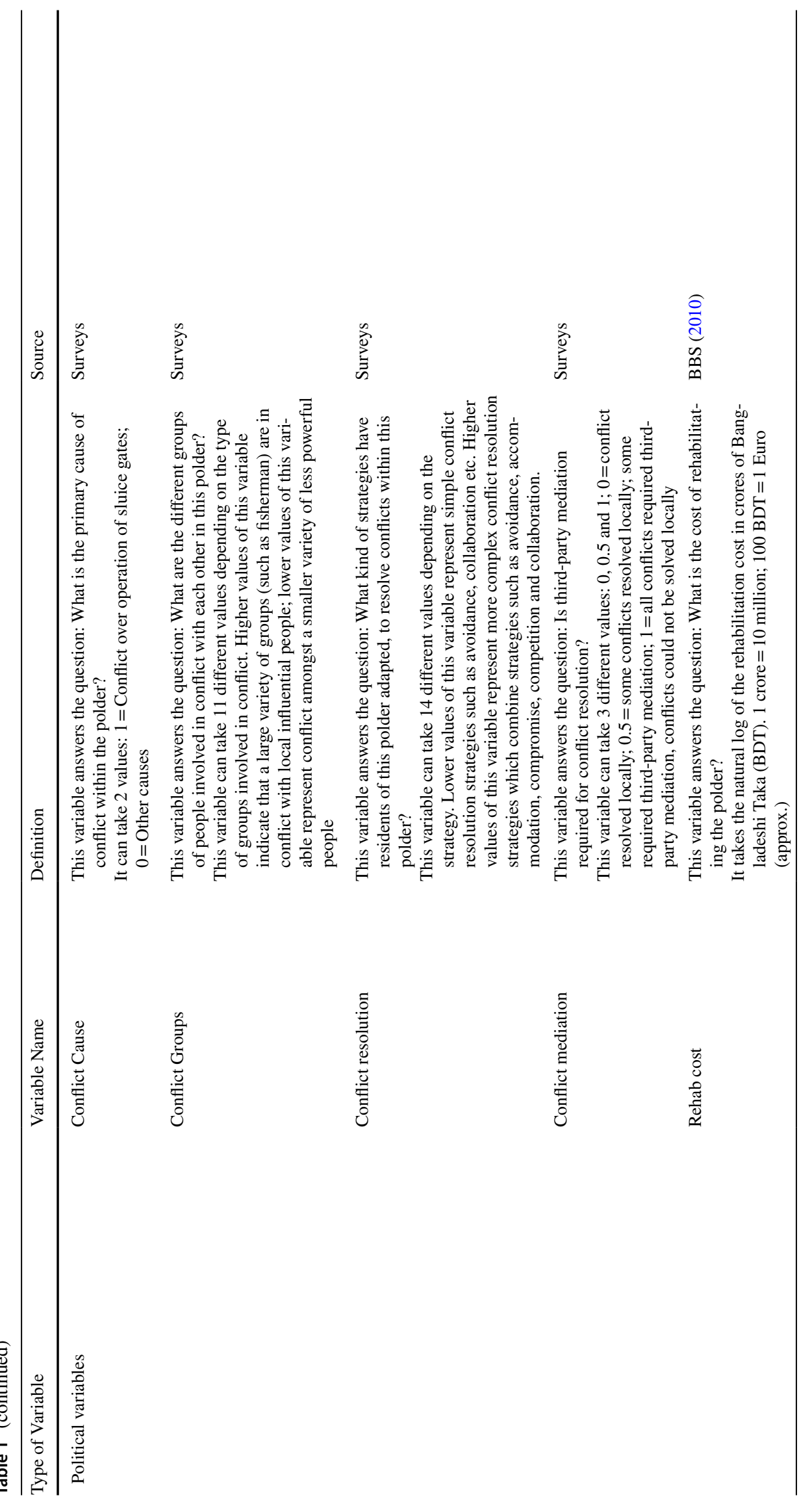


geared towards developing a large-N, cross-sectional dataset with each row in the dataset representing one of the polders. Therefore, first, indicators were developed for each variable in the theoretical model. Second, extensive secondary research was conducted to determine whether open-source or proprietary databases exist for measuring each indicator. Third, open-source, secondary data (including maps) was collected, wherever it was possible; and, proprietary databases (including maps) were procured, wherever available. Fourth, a detailed survey questionnaire was developed for the primary collection of data. Fifth, primary data was collected. 76 BWDB officials responsible for administering the 137 polders were surveyed using the survey instrument over a 4 month period, between Sep-2018 and Dec-2018. The surveys were then triangulated to obtain aggregate scores for each polder. GIS (\& spatial) analysis was conducted in parallel, to extract numerical information (for statistical analysis) from the maps. Sixth, the large-N, dataset was developed by combining the primary and secondary data. Seventh, statistical analysis was conducted on this dataset.

Appendix 2 of the Supplementary File contains the following additional details on the data collection process used for this research:

(a) List of secondary data (including maps) used for preparing the large- $\mathrm{N}$ dataset.

(b) Process followed for developing and testing the questionnaire.

(c) Questionnaire used for the surveys.

(d) Process followed for conducting the surveys.

(e) Profile of survey respondents.

(f) Triangulation.

\section{Data analysis}

The level of analysis is a geo-political region (coastal belt of Bangladesh). The unit of analysis is a polder. The dependent variables and the independent variables used in regression analysis are derived from the equations outlined in Fig. 2 and are defined below in Table 1.

The dependent variable for Eq. 1 is ordered and ranked. It takes 12 values. Since the number of values that the dependent variable takes is greater than 5, ordinary multiple regression using OLS assumptions were used for analysis in Stata. The model was tested for model specification error, linearity errors, multi-collinearity, homoscedasticity of residuals, and normality of residuals. The model demonstrated no such error, after correcting for unusual and influential data.

The dependent variables for Eqs. $2 a$ and $2 b$ are also ordered and ranked. These dependent variables take 5 values. Therefore, proportional odds ordered logistic regression techniques were used for testing these equations in Stata 


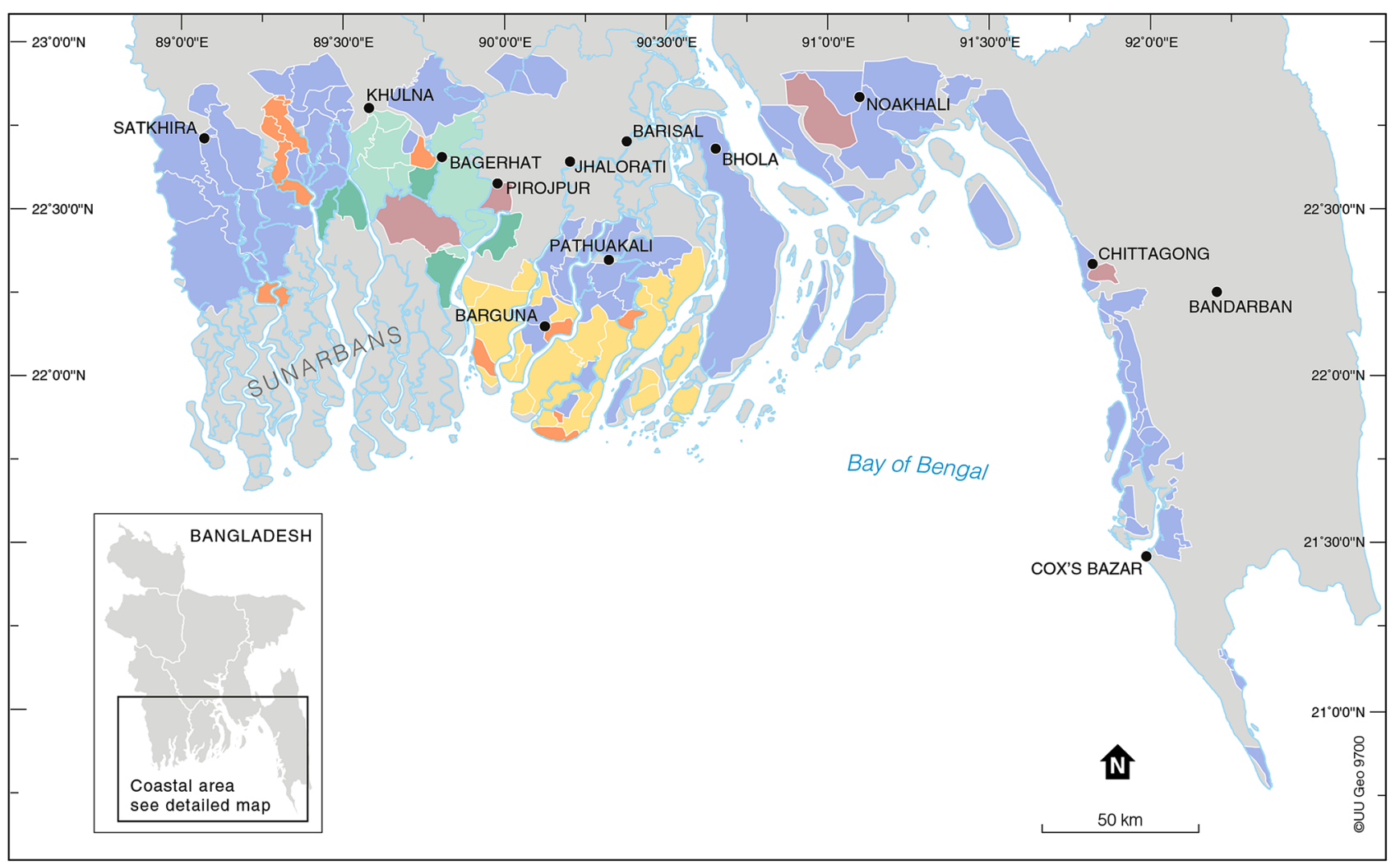

Map 1 Geographical spread of the polders of Bangladesh. Adapted from Google Maps (2019) and BWDB (2012c)

(Burnham and Ma 2017). 4 different models were tested for Eq. 2a. 2 different models were tested for Eq. 2b. This is because different groups of independent variables affect the two dependent variables under different circumstances. The models were tested for model specification error, multicollinearity and whether the models met the proportional odds assumption. These errors were not detected in the tested models. 7 different models were developed and tested because different combinations of independent variables affect the dependent variables in different ways. These results are summarized and discussed in the next section.

\section{Findings}

Table 2 summarizes the findings of regression analysis. Summary statistics on all the variables and the results of the regression analysis (according to model) are detailed in Appendix 3 of the Supplementary File. In general, these findings highlight 6 major points.

It appears that the type of livelihood strategies (selfemployment vs. migration or agriculture vs. non-agriculture) adopted by polder-residents affects both the resilience of polder-infrastructure and the vulnerability of polder-residents (Models 2 and 3 in Table 2). Agriculture has historically been the dominant source of livelihood in most polders. In polders where agriculture is sufficient to meet the day-today requirements of residents and migration levels are low, residents are less vulnerable to the effects of extreme events and other shocks. Social capital is high. When faced with sudden shocks and disturbances, residents self-organize and perform stop-gap infrastructural maintenance-activities on their own, in the absence of immediate action by public officials. On the long term, they can also effectively pressurize public officials to invest in more intensive, large-scale infrastructure-maintenance activities. In other words, the infrastructure is more resilient in such polders. However, if agriculture becomes less viable because of various demographic, socio-economic and climatic reasons, outward migration increases. Residents are forced to seek other forms of livelihood (shrimp-farming, brick-making, etc.). However, these forms of livelihood are viable only in those areas which are more difficult to live as they are characterized by higher levels of salinity and are more prone to natural disasters. Residents come under the influence of unscrupulous, rentseeking employers. Social capital gets reduced. Vulnerability 
Table 2 Summary of findings

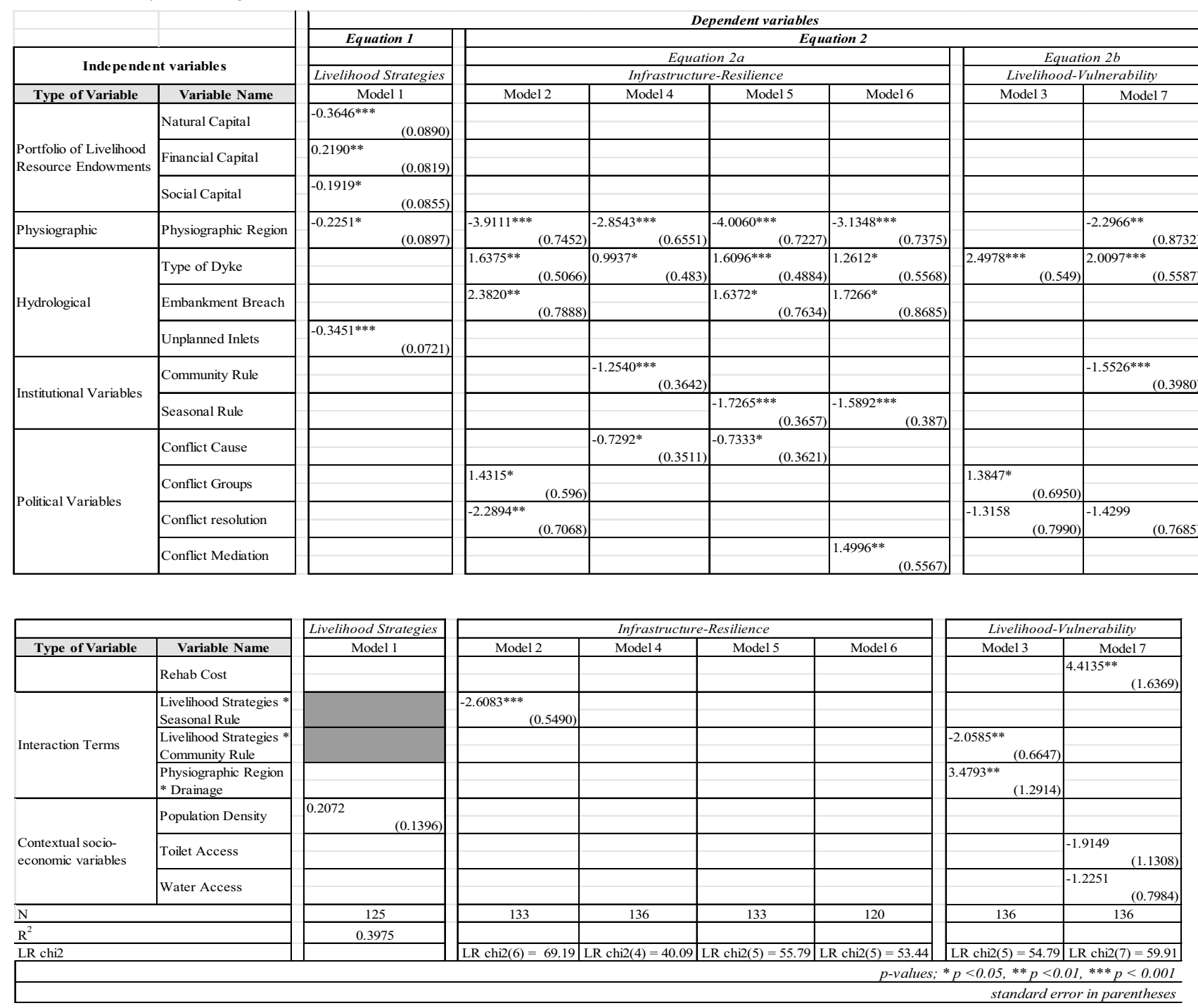

The grey blocks in this table represent those relationships which were not tested. These relationships were not tested because of the manner in which the SLA argues about how these variables affect each other. For instance, the SLA argues that various forms of capital affect livelihood strategies. Livelihood strategies, in turn, affect vulnerability and resilience. See hypothesis (Section "Study site") and Table 1

levels increase and residents become less capable to adapt to natural disasters. In such polders, there is a perverse incentive to weaken the embankments (so that saline water can be introduced into the lands to encourage shrimp-farming) or, to carry out sand-mining for brick factories. Infrastructureresilience in such polders is thus low.

The portfolio of livelihood strategies adopted by polder residents appears to be affected by the portfolio of livelihood resource endowments that polder-residents have access to. Three kinds of livelihood resource endowments (natural capital, financial capital, and social capital) are considered in this article. All the three kinds of capital affect livelihood strategies. As proposed by the SLA, the resource-base that residents have access to, affects their livelihood strategies. Access to financial capital may enable residents to adopt financially-intensive forms of livelihood options (such as purchasing motor-bikes for providing transportation services). Access to natural capital may enable residents to adopt forms of livelihood which are more dependent on land-based resources (such as agriculture). Access to social capital may enable residents to pursue livelihood strategies which require more coordinated action (Scoones 1998) or may enable residents to access other kinds of resources in times of emergencies (such as short-term loans for buying farm equipment.). 
It seems that the rule-making process used for managing polder infrastructure affects outcomes within a polder (Frey 2017). This article analyzes the rule-making process in two ways: a) whether polder-residents have a say in the rule-making process; and, b) whether seasonal rules ${ }^{1}$ are used for operating the sluicegates. Livelihood-vulnerability is lower and infrastructure-resilience is higher in polders when polder-residents have a say in the rule-making process. If residents have no say in the operation of the sluicegates, they have no control over how water flows in and out of the sluicegates. Increasing salinity levels in a polder often increase vulnerability levels and if residents have no control over the flow of saline-water into their lands, their vulnerability increases. In addition, if residents have no say in the rule-making process, in the face of shocks or disturbances, their ability to undertake quick, adaptive infrastructureprotection activities gets hampered. Therefore, livelihoodvulnerability is higher and infrastructure-resilience is lower in polders when polder-residents have no say in the rulemaking process. Livelihood-vulnerability of residents is not affected by whether seasonal rules are used for operating the sluicegates in polders. This is probably because livelihood vulnerability is not seasonal but is more dependent on aggregate salinity levels in the polder. For instance, daily tidal surges bring saline-water into the polders, and if the operation of sluicegates is not timed with the tidal surges, saline-water continues to enter the polders, irrespective of whether seasonal rules control the operation of sluicegates. Infrastructure-resilience is, however, affected by the seasonal rules used for operating sluicegates. This is probably because the infrastructure in a polder, especially the embankments, is subject to erosion and damage every year due to floods during the monsoon season. Having seasonal rules controlling the flow of water during the flood season probably reduces damages to the infrastructure, thus increasing its resilience.

Conflict is an essential component of decision-making processes (van Laerhoven and Andersson 2013; Frey 2017). Therefore, it is not surprising that in our study a range of conflict-related variables (each capturing a different subdimension of conflict) appear to affect outcomes in polders: (a) types of groups involved in conflict; (b) types of strategies adopted to resolve conflict; and (c) whether third-party mediation is required for the conflict resolution. As the number of groups involved in conflict increases, livelihood-vulnerability increases and infrastructure-resilience decreases. This is probably because the intensity of conflict increases as the number of groups increases. When the intensity of

\footnotetext{
${ }^{1}$ Such as: in certain polders, all sluicegates are closed during the monsoon period, so that sea-water does not enter the polders; in other polders, fresh-water is not allowed to leave the polder during the months of December and January.
}

conflict is low, polder-residents use a wide range of strategies (collaboration, competition, compromise, accommodation, and avoidance) to resolve the conflict (Thomas 1992). Polder-residents seek to resolve the conflict locally, without third-party mediation (van Laerhoven and Andersson 2013). As the intensity of conflict increases, residents gradually seek to accommodate the demands of their opponents; when this strategy fails, they seek compromise. However, as the intensity of conflict continues to increase, residents finally run of strategies to resolve conflict and seek third-party mediation.

Hydrological variables (type of embankment and unplanned inlets) also seem to have an effect on polder outcomes. Sea-facing embankments are less resilient and are associated with higher levels of livelihood-vulnerability as compared to embankments located farther away from the sea. This is because the effects of man-made climate change, tidal surges, increase in salinity, flooding and erosion are greater in polders located nearer the sea (BWDB 2012c). The number of unplanned inlets in a polder has a statistically significant relationship with the type of livelihood strategies practiced in polders (see Model 1 in Table 2). Typically, a higher number of unplanned inlets are observed in polders in which a significant chunk of resources is dedicated to shrimp-farming. This is because unplanned inlets are created to increase the flow of saline water into polders. Increasing salinity benefits shrimp farming. Therefore, polders in which residents are more dependent on services-oriented livelihood strategies have a lower number of unplanned inlets as compared to polders associated with aquaculture. Other hydrological variables are mainly used as controls. The effect of these variables on outcome variables is either minimal or statistically insignificant. The cost of rehabilitating polders is another variable used as a control variable. Similarly, a number of contextual socio-economic variables are also used as controls. The effect of these contextual variables on outcome variables is statistically insignificant, in most of the tested models.

The polders under consideration are heterogeneous in nature. They are spread across a wide landscape and vary in terms of geological, geomorphological, climatic and hydrological conditions. To account for such heterogeneity, Brammer (2012) mapped the coastal belt of Bangladesh into a wide range of physiographic regions. In this article, these physiographic regions are used for controlling heterogeneity in polders during regression analysis. Nonetheless, the physiographic regions in which the polders are located bear a statistically significant relationship with the livelihoodvulnerability and infrastructure-resilience of polders. 


\section{Discussion and conclusion}

These results have two kinds of implications: (a) theoretical implications for the SLA; and, (b) empirical implications for livelihood-vulnerability and infrastructure-resilience in polders. In terms of theoretical implications, two broad conclusions can be drawn. Scoones (2015) had called for more quantitative studies using the SLA to statistically evaluate whether the relationships proposed by the approach hold across larger data-sets. This research upholds such theoretical relationships. The relationships proposed by the SLA are statistically significant and are generalizable across a large number of heterogeneous sites. While Scoones (1998, 2015) has argued that institutional and political variables affect livelihood and sustainability outcomes, other scholars (Allison and Horemans 2006; Moser 2008; de Haan and Zoomers 2005) have argued that the political dimensions of human interactions (conflict, rule-making, etc.) have not been adequately captured in the SLA. This research demonstrates that various kinds of conflict-related and rule-making variables do affect sustainability outcomes. Empirically, this research throws light on the various factors which affect the resilience of polder-infrastructure and the vulnerability of polder-residents.

As discussed in the Introduction, Bangladesh is not the only country which has polders along its coastal belt. Polder-like structures have been constructed across the world. However, no comprehensive, large-scale study has yet been conducted on the effect such structures have on livelihood and sustainability outcomes. Drawing on a data-set of polders from Bangladesh, this article has analyzed how various institutional, political, socio-economic and physiographic factors affect outcomes in polders. The theoretical propositions tested in this article are drawn from the Sustainable Livelihood Approach (SLA). These propositions have been qualitatively derived from studies conducted across the world. Therefore, the findings of this article should also be generalizable for polder-like structures across the worldwith a few caveats: socio-economic and political conditions vary dramatically at the macro-level, from country to country. A global study of polders needs to control for such variation. Feedback effects need to be considered. The SLA suggests that outcome variables also effect contextual and independent variables, via feedback loops. However, for the sake of simplicity, such feedback effects have been ignored in this article. Due to the paucity of data, the effect of factors like drainage congestion could not be considered. Analyzing the effect of such factors will throw additional light on the pros and cons of polderization. Additional research also needs to be conducted for identifying those variables which differentially affect livelihood vulnerability but not infrastructure resilience (and vice versa) and for identifying and explaining interrelationships between such variables. In addition, future research needs to identify contextual socioeconomic variables which affect livelihood strategies, infrastructure resilience and livelihood vulnerability in polders.

A few practical lessons can be drawn from this study. The resource-base (natural, social and financial) affects livelihood strategies of polder residents. However, the construction of unplanned inlets often changes the resource-base. This can alter the livelihood choices available to residents with negative repercussions for livelihood vulnerability. In addition, the unplanned inlets often affect the resilience of polder-infrastructure negatively. The construction of these unplanned inlets often take place with the active cognizance of public officials. Therefore, the role of public officials in the construction of the unplanned inlets needs to be looked into. The polders of Bangladesh are highly contentious. A wide range of interest groups are active. The goals and motivations of these groups vary widely. Wide power imbalances exist. Therefore, when conflicts take place, the most-vulnerable residents often are not able to use appropriate conflict resolution strategies to ensure that the conflict ends in their favor. Third-party mediation often becomes necessary to ensure that conflict resolution results in equitable solution.

Therefore, to conclude this article, in addition to socioeconomic and political conditions prevalent in polders (as hypothesized by the SLA), geological, geomorphological, climatic and hydrological conditions also affect the livelihood decisions of polder-residents and also affect the condition of the polder-infrastructure. In other words, context matters (Frey 2017). Panaceas do not always succeed (Ostrom et al. 2007).

Acknowledgements This research was funded by the Netherlands Organization for Scientific Research (NWO), grant number W.07.69.201. It is part of the Living Polders project, carried out by a consortium of partners. Living Polders is part of NWO's Urbanizing Deltas of the World (UDW) program. This article would not have seen the light of day had the talented Afsana Afrin Esha not spent long hours on the phone coaxing BWDB officials, from all over Bangladesh, to answer our long questionnaire. Thanks to Veena Sreenivasan for connecting me to Ganesh Shinde who provided me with excellent GIS support. Thanks to Saidur Rahman for taking time off from work for helping me design the research for this article. Special thanks to my mom, Rita Nath, for sitting with me during the Covid Lockdown and helping me proof-read the numbers which found their way into all the tables in the manuscript and the supplementary file.

Open Access This article is licensed under a Creative Commons Attribution 4.0 International License, which permits use, sharing, adaptation, distribution and reproduction in any medium or format, as long as you give appropriate credit to the original author(s) and the source, provide a link to the Creative Commons licence, and indicate if changes were made. The images or other third party material in this article are included in the article's Creative Commons licence, unless indicated otherwise in a credit line to the material. If material is not included in the article's Creative Commons licence and your intended use is not permitted by statutory regulation or exceeds the permitted use, you will 
need to obtain permission directly from the copyright holder. To view a copy of this licence, visit http://creativecommons.org/licenses/by/4.0/.

\section{References}

Adger WN (2006) Vulnerability. GlobEnviron Change 16(3):268-281 Adnan MSG, Haque A, Hall JW (2019) Have coastal embankments reduced flooding in Bangladesh? Sci Total Environ 682:405-416

Akber MA, Khan MWR, Islam MA, Rahman MM, Rahman MR (2018) Impact of land use change on ecosystem services of southwest coastal Bangladesh. J Land Use Sci 13(3):238-250

Alam MS, Sasaki N, Datta A (2017) Waterlogging, crop damage and adaptation interventions in the coastal region of Bangladesh. A perception analysis of local people. Environ Dev 23:22-32

Allison EH, Horemans B (2006) Putting the principles of the Sustainable Livelihoods Approach into fisheries development policy and practice. Mar Policy 30(6):757-766

BBS (2010) Census of Agriculture 2008. Structure of Agricultural Holdings and Livestock Population. Bangladesh Bureau of Statistics (BBS), Government of the People's Republic of Bangladesh

BBS (2014a) Bangladesh Population and Housing Census 2011. Bangladesh Bureau of Statistics (BBS), Government of the People's Republic of Bangladesh

BBS (2014b) Bangladesh Population and Housing Census 2011. Zila Reports. Bangladesh Bureau of Statistics (BBS), Government of the People's Republic of Bangladesh (ISBN-978-984-519-068-8)

BBS (2015) Bangladesh Population and Housing Census 2011. Community Reports: Zila Series. Bangladesh Bureau of Statistics (BBS), Government of the People's Republic of Bangladesh.BBS (2014): Bangladesh Population and Housing Census 2011. Zila Reports. Bangladesh Bureau of Statistics (BBS), Government of the People's Republic of Bangladesh

Brammer H (2012) The physical geography of Bangladesh. The University Press Limited, Dhaka

Brand FS, Jax K (2007) Focusing the meaning(s) of resilience: resilience as a descriptive concept and a boundary object. Ecol Soc 12(1):23

Burnham M, Ma Z (2017) Climate change adaptation: factors influencing Chinese smallholder farmers' perceived self-efficacy and adaptation intent. Reg Environ Change 17(1):171-186

BWDB (2012a) Social Management Plan (SMP), Polder 39/2A. Bangladesh Water Development Board, Ministry of Water Resources, Government of the People's Republic of Bangladesh

BWDB (2012b) Social Management Plan (SMP), Polder 41/7B. Bangladesh Water Development Board, Ministry of Water Resources, Government of the People's Republic of Bangladesh

BWDB (2012c) Final Report, Volume VIII: Social \& Environmental Reports, Coastal Embankment Improvement Project, Phase-I (CEIP-I), Consultancy Services for "Technical Feasibility Studies and Detailed Design for Coastal Embankment Improvement Programme (CEIP)"Contract Package No. BWDB/D2.2/S-3

BWDB (2013) Coastal Embankment Improvement Project, Phase-I, (CEIP-I). Detailed Design Of Five Polders; Volume III: Environmental Impact Assessment; Part D: Polder No 35/3. Bangladesh Water Development Board, Ministry of Water Resources, Government of the People's Republic of Bangladesh

Chambers R, Conway G (1992) Sustainable rural livelihoods: practical concepts for the 21st century. IDS discussion paper 296. Institute of Development Studies, Brighton, England
Chang SE (2014) Infrastructure resilience to disasters. The Bridge 44(3):36-41

Cheung WWL, Lam VWY, Sarmiento JL, Kearney K, Watson R, Pauly D (2009) Projecting global marine biodiversity impacts under climate change scenarios. Fish Fish 10(3):235-251

Cutter SL, Barnes L, Berry M, Burton C, Evans E, Tate E, Webb J (2008) A place-based model for understanding community resilience to natural disasters. Glob EnvironChange 18(4):598-606

Dasgupta S, Huq M, Khan, Malik F, Pandey K, Ahmed MMZ, Khan, Zahirul H, Mukherjee N (2010) Vulnerability of Bangladesh to cyclones in a changing climate. potential damages and adaptation cost. World Bank, Development Research Group. Policy Research Working Paper, 5280

de Haan L, Zoomers A (2005) Exploring the Frontier of Livelihoods Research. Dev Change 36(1):27-47

Di Baldassarre G, Viglione A, Carr G, Kuil L, Salinas JL, Blöschl G (2013) Socio-hydrology: conceptualising human-flood interactions. Hydrol Earth Syst Sci 17(8):3295-3303

Frey UJ (2017) A synthesis of key factors for sustainability in socialecological systems. Sustain Sci 12(4):507-519

Gallopın GC (2006) Linkages between vulnerability, resilience, and adaptive capacity. Glob Environ Change 16(3):293-303

GED (2017) Bangladesh Delta Plan 2100: Draft. Government of the People's Republic of Bangladesh, Bangladesh Planning Commission, General Economics Division, Dhaka, Bangladesh

Google Maps (2019) Google Maps, https://www.google.nl/ maps/place/Bangladesh/@23.4521774,81.3634705,5z/ data $=! 4 \mathrm{~m} 5 ! 3 \mathrm{~m} 4 ! 1 \mathrm{~s} 0 \times 30$ adaaed80e $18 \mathrm{ba} 7: 0 \times f 2 \mathrm{~d} 28 \mathrm{e} 0 \mathrm{c} 4 \mathrm{e} 1 \mathrm{fc}$ $6 \mathrm{~b} ! 8 \mathrm{~m} 2 ! 3 \mathrm{~d} 23.684994 ! 4 \mathrm{~d} 90.356331 ? \mathrm{hl}=\mathrm{en}$. Accessed $9 \mathrm{Apr}$ 2020

Hahn MB, Riederer AM, Foster (2009) The Livelihood Vulnerability Index: a pragmatic approach to assessing risks from climate variability and change - q case study in Mozambique. Glob Environ Change 19(1):74-88

Inniss L, Simcock A (2016) The First Global Integrated Marine Assessment. World Ocean Assessment I. Cambridge University Press, Cambridge

Ishtiaque A, Sangwan N, Yu DJ (2017) Robust-yet-fragile nature of partly engineered social-ecological systems: a case study of coastal Bangladesh. Ecol Soc 22(3):5

Jr Auerbach LWSLG, Mondal DR, Wilson CA, Ahmed KR, Roy K, Steckler MS, Small C, Gilligan JM, Ackerly BA (2015) Flood risk of natural and embanked landscapes on the Ganges-Brahmaputra tidal delta plain. Nclimate 5(2):153-157

Kreft S, Eckstein D, Melchior I (2016) Global Climate Risk Index 2017. Who Suffers Most From Extreme Weather Events? Weather-related Loss Events in 2015 and 1996 to 2015. GermanWatch, Bonn

McDaniels T, Chang S, Cole D, Mikawoz J, Longstaff H (2008) Fostering resilience to extreme events within infrastructure systems: characterizing decision contexts for mitigation and adaptation. Glob Environ Change 18(2):310-318

McLennan B, Garvin T (2012) Intra-regional variation in land use and livelihood change during a forest transition in Costa Rica's dry North West. Land Use Policy 29(1):119-130

Mersha AA, van Laerhoven F (2016) A gender approach to understanding the differentiated impact of barriers to adaptation: responses to climate change in rural Ethiopia. Reg Environ Change 16(6):1701-1713

Miller F, Osbahr H, Boyd E, Thomalla F, Bharwani S, Ziervogel G, Walker B, Birkmann J, van der Leeuw S, Rockström J, Hinkel J, 
Downing T, Folke C, Nelson D (2010) Resilience and vulnerability: complementary or conflicting concepts? Ecol Soc 15(3):11

Morse S, McNamara N (eds) (2013a) Sustainable livelihood approach. Springer Netherlands, Dordrecht

Morse S, McNamara N (2013b) The theory behind the sustainable livelihood approach. In: Morse S, McNamara N (eds) Sustainable livelihood approach. Springer Netherlands, Dordrecht, pp 15-60

Moser C (2008) Assets and livelihoods: a framework for asset-based social policy. In: Moser C, Dani AA (eds) Assets, livelihoods and social policy. The World Bank. Washington DC, pp 43-82

Mukhopadhyay A, Hornby DD, Hutton CW, Lázár AN, Johnson FA, Ghosh T (2018) Land cover and land use analysis in coastal Bangladesh. Ecosystem services for well-being in deltas. Palgrave Macmillan, Cham, pp 367-381

Naz F, Buisson M-C (2015) Multiple actors, conflicting roles and perverse incentives. The case of poor operation and maintenance of coastal polders in Bangladesh. In: Conference: revitalizing the Ganges Coastal Zone: Turning Science into Policy and Practices

Nelson DR, Adger WN, Brown K (2007) Adaptation to environmental change: contributions of a resilience framework. Annu Rev Environ Resour 32(1):395-419

Ostrom E, Janssen MA, Anderies JM (2007) Going beyond panaceas. PNAS 104(39):15176-15178

Pande S, Sivapalan M (2017) Progress in socio-hydrology: a meta-analysis of challenges and opportunities. WIREs Water 4(4):e1193

Renaud FG, Syvitski JPM, Sebesvari Z, Werners SE, Kremer H, Kuenzer C, Ramesh R, Jeuken A, Friedrich J (2013) Tipping from the holocene to the anthropocene how threatened are major world deltas? Curr Opin Environ Sustain 5(6):644-654
Scoones I (1998) Sustainable rural livelihoods: a framework for analysis. IDS working paper No 72. Institute of Development Studies, Brighton, England

Scoones I (2015) Sustainable livelihoods and rural development. Agrarian change and peasant studies. Practical Action Publishing, Rugby. https://doi.org/10.3362/9781780448749

Segeren WA (ed) (1982) Keynotes: Polders of the world. In: International symposium, Lelystad, The Netherlands. https://edepot.wur. nl/380818. Accessed 15 May 2020

Thomas KW (1992) Conflict and negotiation processes in organizations. In: Dunnette MD, Hough LM (eds) Handbook of industrial and organizational psychology. Consulting Psychologists Press. Palo Alto, CA, pp 651-717

Turner BL II (2010) Vulnerability and resilience: coalescing or paralleling approaches for sustainability science? Glob Environ Change 20(4):570-576

van Laerhoven F, Andersson KP (2013) The virtue of conflict: an institutional approach to the study of conflict in community forest governance. Int For Rev 15(1):122-135

WB (2015) Bangladesh-Country snapshot (English). Washington, D.C. : World Bank Group. http://documents.worldbank.org/curat ed/en/190391468190764030/Bangladesh-Country-snapshot. Accessed 9 Apr 2020

Publisher's Note Springer Nature remains neutral with regard to jurisdictional claims in published maps and institutional affiliations. 